\title{
The Security and Exchange Commission's Development of Accounting Standards ..- A Note on Commissioner Healy's Address*
}

THE emphasis placed upon judicial review of administrative action 1 has tended to obscure the importance of many matters decided without appeal to the courts. The lawyer interested in transactions governed by administrative agencies must, therefore, be cognizant of the many decisions and rulings that are never judicially construed. He must, if he aims to be au courant, be conversant likewise with the trend of opinion within an administrative agency-trends that are never formally reduced to either rule or decision.

Such a trend is often best revealed in the addresses of the officials administering the statutes. These addresses frequently are reproduced in the metropolitan press and are distributed to mailing lists. Lawyers frequently have no convenient access to them, however. For this reason, a recent address of Commissioner Healy of the Securities and Exchange Commission, which contains important discussion of S.E.C. thought on accounting problems, is significant enough to merit the attention of the readers of the California Law Review.

Conmissioner Healy introduces his discussion by emphasizing the importance of accounting questions to the corporation lawyer. He then launches into the only available public discussion by any representative of the Commission of a series of cases dealing with the proper treatment of the aniortization of bond discount and expense. The Northern States Power Company case is the best known of these and will illustrate the situation which brought about the most serious disagreement thus far among the Commissioners.

"Prior to 1924 the Northern States Power Company followed the practice of amortizing debt discount and expense by charges against income over the lives of the respective issues. In 1924 there was an appraisal made of its properties by an affiliate. It was never passed upon by any regulatory body; it was based wholly on an estimate of the cost of reproducing the property new and in arriving at present value it gave consideration to no other element. On the basis of this appraisal the company wrote up its fixed capital and investnent accounts approxi-

* Healy, Robert E., Commissioner, Securities and Exchange Commission, The Next Step in Accounting. Address before the Annual Meeting of the American Accounting Association, Atlantic City, N. J., December 27, 1937. To be published in Tee Accountring Review for March, 1938. 
mately $\$ 15,000,000$, crediting about $\$ 7,000,000$ thereof to a retirement reserve and about $\$ 8,000,000$ to capital surplus. In 1924 and 1925 the registrant wrote-off substantially all of its unamortized debt discount and expense against capital surplus. The effect of this write-off was to relieve the income account prior to the clate of registration, August 31, 1934 , of amortization charges of about $\$ 5,000,000$. The accountants in their certificate described the transaction and the effect thereof substantially as $I$ have, and thereupon after saying: 'Subject to the foregoing comments,' certified to the statement. Before the registration became effective the clause quoted was amended to read, 'Except for the matters discussed in the foregoing comments.' The auditors did not indicate otherwise either approval or disapproval of the accounting procedure. All the commissioners disapproved the accounting. The majority believed that there was such a complete disclosure in the statement as to comply with the statute and make a stop order proceeding improvident, and further, that the accountants' certificate had, in effect, condemned the accounting. The minority took the view that the accountants had expressed no clear opinion as to whether the accounting was good or bad, that the company's earnings record and earned surplus balance as stated in the registration were in effect untrue-amounted to misrepresentations and therefore were violations of the statute....

"The argument as I have tried to indicate revolved about differences as to the law rather than differences as to accounting. I regret that an attempt was not made in these cases to establish the principle that if an earnings statement and a balance sheet reflect the results of improper accounting, they amount to misrepresentations or misleading statements in violation of the Securities Act. In the absence of a court decision I have no right to go further than to reiterate the regret that an effort to have the questions settled by a court decision was not made. The policy of the Commission evidenced by those decisions has been followed in a number of subsequent cases, although there lias been a pronounced improvement in the treatment of debt discount in registration statements.

"The Commission has slown a tendency to depart from this policy somewhat. Thus the Commission took a firm position against a registrant in the following circunstances. The company had purchased a property at arms length bargaiming from strangers. It paid, let us say, $\$ 400,000$ (the figures are assumed), it had a reproduction appraisal made which showed a valuation of $\$ 1,000,000$. It recorded its property at $\$ 1,000,000$, credited $\$ 600,000$ to capital surplus and announced its intention of clarging off certain items such as organization expense against this surplus. The Commission protested, threatened stop-order proceedings and the company reversed the entries and recorded its properties at cost, 
$\$ 400,000$. This precedent has been followed in several other cases. The circumstances did not then seem to require a formal public opinion or release concerning any of them. I now think, however, that the publication of such instances, possibly with names omitted would be so informative to accountants and prospective registrants, that it should be required.

"In the Northern States case and the other cases described, the majority thought it might not be entirely fair to proceed against the registrants since the Commission had not promulgated the rules on the subject of accounting whicl the Securities Act seems to authorize. This brings me to the first of the next steps in accounting which I am to describe."

Commissioner Healy then proceeds to a consideration of the advisability of promulgating accounting standards under the Securities Act that would combat the abuse of reproduction cost appraisals sucli as were revealed in the Northern States Power case, for example. He emphasizes tlrat accounting to lim "neans the making of a historical record of financial events," and continues:

"But there are other matters with which the rules must deal. Writedowns made for the purpose of decreasing depreciation allowances and increasing net income nust be dealt with. So eventually nust the uses to which capital surplus can be put. The proper treatnent of the undistributed earnings of subsidiaries nuust be on the agenda, and the whole subject of the proper handling of debt discount, and the cliarging off of losses and expenses against a reduction of capital stock while earned surplus remains undisturbed. High up on the list must appear an item dealing with that excrescence, that abomination which clarter-mongering states-corporation 'Renos,' (inspired perliaps by the states competing for divorce cases), lave put upon us in their 'liberalization' of corporation laws. I refer to that kind of preferred stock whicl, let us say, is issued for $\$ 50$ a share, pays a dividend of $\$ 3$ a share, las a call price of $\$ 52$, is entitled upon liquidation to $\$ 50$ in preference and has a par value of $\$ 40$. The Conpany issuing it brings us the balance sheet on which the preferred is carried at $\$ 40$ a share and $\$ 10$ a slrare is carried to a paid-in surplus account. We have seen many such. The company's lawyers tell us in written opinions that there is no restriction upon the use of this surplus, that it can be paid out to the common stockholders in dividends. Only one lawyer has filed an opinion with us that a court of equity would in such circumstances restrain the payment to the common stockholders of the $\$ 10$ capital contributed by the preferred stockholders. We are told we must accept the balance sheet in the form I have described because the law permits the unrestricted use of the surplus created in the mauner I have described. The stock is a $\$ 50$ stock in 
every essential respect except the one which is of the least importance, the par value. Practices such as these menace the welfare of capitalism. Those responsible for them should take heed lest in winning too many such battles they lose the war. Many of you have had similar experiences where the accountant's objection is met by the corporation's lawyer who is called in to say that the law permits that to which the accountant objects. The lawyer swallows or cooks up what the accountant gags over. A little more discretion in some of the third houses would aid the cause of accountancy. These are not mere academic bookkeepers' arguments. They go to the very vitals of investment appraisal and corporate responsibility. 'Accountancy,' a famous French financier is reported to have said, 'is government.' It is the heartbeat of modern corporate finance."

The proposed simphified form for seasoned corporations is the final topic discussed by Commissioner Healy. A clearer statement by the accountant with respect to his opinion on the accounting policies to be pursued; a segregation of surplus for corporations organized after January 1,1928; and, for those corporations organized prior to that date, the requirement will be the present form plus an additional segregation for any surplus arising from revaluation, and if there is no such segregation, a descriptive caption to indicate the kinds of surplus in any combined account; and under "Historical Information," which is not certified by the auditors, a review of the surplus accounts for each of seven years preceding the three-year period reviewed by the auditor-these are important changes likely to be found in the new form.

Brunson MacChesney. 